\title{
Physiologic and cellular insulin action in a glucose-intolerant model of Type 2 (non-insulin-dependent) diabetes in rats
}

\author{
B. L. Maloff and B. K. Boyd \\ Metabolic Diseases Section, Biomedical Products Department, E. I. DuPont de Nemours and Company, Inc., Wilmington, Delaware, USA
}

Summary. A B-cell-deficient model for Type 2 (non-insulindependent) diabetes mellitus has been investigated with regard to insulin action at the cellular level. Two-day-old male Sprague Dawley rats were injected with streptozotocin $(90 \mathrm{mg} / \mathrm{kg})$ or citrate buffer. At 6 weeks streptozotocin-treated animals were hyperglycaemic and exhibited glucose intolerance, e.g. at $45 \mathrm{~min}$ post-glucose $(1.5 \mathrm{~g} / \mathrm{kg})$ the change in serum glucose level from baseline was $6 \pm 7 \mathrm{mg} \%$ in control rats vs. $212 \pm 18 \mathrm{mg} \%$ for the streptozotocin-treated rats. Basal activity and insulin action in isolated adipocytes, as estimated by 2-deoxyglucose uptake and glucose metabolism, were not influenced by streptozotocin treatment. For example, uptake of $0.1 \mathrm{mmol} / 1$ 2-deoxyglucose at $1000 \mu \mathrm{U}$ insulin $/ \mathrm{ml}$ was $58 \pm$ $8 \mathrm{pmol} / 10^{5}$ cells $\mathrm{min}^{-1}$ vs $54 \pm 6 \mathrm{pmol}$ for adipocytes isolated from experimental vs. control animals. Although serum insu- lin levels in streptozotocin-treated rats were significantly decreased $(p<0.05)$, there was no difference in insulin receptor number or affinity. Glucose intolerance present in this model is similar to that in Type 2 diabetes. However, concomitant insulin intolerance was not observed. Taken together with our findings of unaltered insulin action at the cellular level, this suggests that the pathogenesis of insulin resistance is not dependent on glucose intolerance. Moreover, this hyperglycaemic model is responsive to oral hypoglycaemic agents and can be used to establish their direct effects on physiologic and cellular insulin action.

Key words: Diabetic models, glucose intolerance, insulin resistance, hyperglycaemia, insulin action, streptozotocin.
The development of more effective therapies for Type 2 (non-insulin-dependent) diabetes may be facilitated by the establishment of animal models with pathophysiology more closely resembling the human disease state. Glucose intolerance concomitant with varying degrees of peripheral insulin resistance are characteristic of non-insulin-dependent diabetes in man [1-4], and recent evidence suggests that defective insulin action may constitute the primary lesion [5-7]. As yet, no animal model has been identified or established in which comparable defects in target tissue insulin responsiveness and glucose tolerance are present.

Recently, attention has been focused on physiologic and cellular insulin action in a new model for Type 2 diabetes involving streptozotocin injection of neonatal rats. This model, first described by Weir et al. [8], is generated by injection of 2-day old rats with $90 \mathrm{mg} / \mathrm{kg}$ streptozotocin. At six weeks post-treatment, these animals are characterized by hyperglycaemia $(\sim 200 \mathrm{mg} / \mathrm{dl}$ glucose). Although the serum insulin levels in these animals are decreased compared to the citrate-injected group, sufficient insulin remains to control the moder- ate hyperglycaemia. Carbohydrate tolerance was evaluated in this model by Levy et al. [9], who monitored glucose disappearance rates following glucose and insulin challenge. They reported reduced glucose disappearance rates in the diabetic animals. In addition, Trent et al. [10] studied glucose oxidation (at 4 and 6 weeks posttreatment) in adipocytes isolated from neonatal animals injected with streptozotocin and found a correlation between abnormal B-cell number and adipocyte function.

The present studies were performed to better characterize this model, with particular emphasis on physiologic insulin tolerance and cellular insulin action. The effect of a standard oral hypoglycaemic agent on lowering glucose levels in these animals was also evaluated.

\section{Materials and methods}

\section{Materials}

Pregnant Sprague-Dawley rats were obtained from Charles River Breeding Laboratories, (Wilmington, MA, USA). Crystalline porcine insulin was a gift of Eli Lilly and Company (Indianapolis, IN, USA). 
NPH (isophane) insulin (100 units/ml) was purchased from the same source. The Na salt of tolazamide was supplied by the Upjohn Company (Kalamazoo, MI, USA). Streptozotocin was purchased from Sigma Chemical Company (St. Louis, MO, USA). Collagenase was obtained from Worthington Biochemical Corporation (Freehold, NJ, USA) and bovine serum albumin fraction $\mathrm{V}$ was supplied by Reheis Company, Inc. (Kankakee, IL, USA). 2-Deoxy-D-[1- $\left.{ }^{3} \mathrm{H}\right]$ glucose $(12 \mu \mathrm{Ci} / \mu \mathrm{mol}$ ) was purchased from Amersham Corporation (Arlington Heights, IL, USA), and D-[U- $\left.{ }^{14} \mathrm{C}\right]$ glucose $(50 \mu \mathrm{Ci} / \mu \mathrm{mol})$ and ${ }^{125} \mathrm{I}-$ insulin (receptor grade, $2.2 \mathrm{Ci} / \mu \mathrm{mol}$ ) were obtained from New England Nuclear (Boston, MA, USA). Radioimmunoassay kits for insulin were purchased from Micromedic Systems, Inc. (Horsham, PA, USA) and rat insulin standard from Novo Research Institute (Copenhagen, Denmark).

\section{Preparation and characterization of model}

Pregnant Sprague-Dawley rats were received and housed approximately 1 week prior to delivery. Male pups were injected with streptozotocin $(90 \mathrm{mg} / \mathrm{kg} ; 0.01 \mathrm{ml} / \mathrm{g}$, intraperitoneal) or citrate buffer ( $\mathrm{pH}$ 4.5). Streptozotocin was dissolved in the citrate buffer, and used within 20 min of preparation. After 3 weeks, the streptozotocin-treated and control animals were weaned and transferred to standard housing and food. Unless otherwise specified, animals were screened at 6 weeks post-treatment to determine serum glucose and insulin levels, and used at that time for experimentation. Glucose and insulin tolerance tests and insulin extractions were run between $0.900-11.00$ hours using non-fasted animals. Glucose $(1.5 \mathrm{~g} / \mathrm{kg})$ or insulin $(0.5$ or $1.0 \mathrm{U} / \mathrm{kg})$ were administered via intraperitoneal injection. Blood samples were collected from the tail vein into microtainer tubes (Becton Dickinson, Rutherford, NJ, USA), and serum was separated by centrifugation. Pancreatic insulin concentrations were determined in some 6-week-old control and streptozotocin-treated rats by dissection of pancreatic tissue into acid/alcohol, followed by mincing and sonication. Homogenates were centrifuged at $500 \mathrm{~g}$, and insulin levels in the supernatants were assayed.

\section{Adipocyte isolation}

Adipocytes were isolated from epididymal fat pads by collagenase treatment $(1 \mathrm{mg} / \mathrm{ml})$ at $37^{\circ}$ for $20 \mathrm{~min}$ with mechanical agitation [11]. Following collagenase digestion, the cells were filtered through silkscreen to remove undigested tissue, and washed twice with KrebsRinger phosphate buffer, $\mathrm{pH} 7.4$, to remove the collagenase. A final cell suspension was prepared by diluting the packed cells $10: 1$, for a final cell concentration of approximately $8 \times 10^{5}$ cells $/ \mathrm{ml}$. Cell number was determined by use of a haemocytometer. Cytosolic spaces were estimated by the method of Gliemann et al. [12].

\section{Insulin binding}

Monoiodinated insulin was used to measure insulin binding to $300 \mu \mathrm{l}$ aliquots of the cell suspension. Binding of the labeled hormone was determined by measuring its displacement with native insulin $(0-5000 \mathrm{ng} / \mathrm{ml})$. The incubations were carried out for $60 \mathrm{~min}$ at room temperature, and terminated by centrifugation for $15 \mathrm{~s}$ at $10000 \mathrm{~g}$ through $100 \mu \mathrm{l}$ of silicone oil [13]. Degradation of labeled insulin was assayed by measuring its precipitance in $5 \%(\mathrm{w} / \mathrm{vol})$ trichloroacetic acid. Specific binding was calculated by taking the difference between total binding of labeled hormone and that amount remaining bound in the presence of a large excess $(5000 \mathrm{ng} / \mathrm{ml})$ of native hormone.

\section{Hexose transport}

Glucose uptake was monitored by measuring the rate of transport of the glucose analog 2-deoxyglucose $(0.1 \mathrm{nmol} / \mathrm{l})$. Aliquots of the cell suspension $(300 \mu \mathrm{l})$ were preincubated for $60 \mathrm{~min}$ with $0-1000 \mu \mathrm{U} / \mathrm{m}]$ of insulin at $37^{\circ} \mathrm{C}$ under a humidified atmosphere of $95 \% \mathrm{O}_{2} / 5 \%$
$\mathrm{CO}_{2}$. The adipocytes were then incubated in the presence of 2-deoxyglucose for $60 \mathrm{~s}$ at $37^{\circ} \mathrm{C}$, after which the cells were separated from the medium by centrifugation through oil. Correction for trapped label in the extracellular space was determined by parallel incubations in the presence of $50 \mu \mathrm{mol} / 1$ cytocholasin B, which specifically blocks glucose transport [14].

\section{Glucose metabolism}

Incorporation of glucose into $\mathrm{CO}_{2}$ was monitored using $300 \mu \mathrm{lali}$ quots of the cell suspension. Cells were diluted to a final volume of $2 \mathrm{ml}$ with Krebs Ringer phosphate buffer ( $\mathrm{pH} 7.4)$ in plastic vials stopped with rubber caps from which polyethylene wells were suspended. Cells were incubated with the labelled glucose for $60 \mathrm{~min}$ at $37^{\circ} \mathrm{C}$ under an atmosphere of $95 \% \mathrm{O}_{2} / 5 \% \mathrm{CO}_{2}$. Injection on $0.2 \mathrm{ml}$ of $6 \mathrm{~N} \mathrm{H}_{2} \mathrm{SO}_{4}$ through the rubber stopper and into the incubation medium was used to terminate the assay and to acidify the medium. $\mathrm{CO}_{2}$ was accumulated by injecting $0.2 \mathrm{ml}$ of hyamine hydroxide into the center well. Cell-free samples of buffer were used to correct for spontaneous counts.

\section{Statistical analysis}

Statistical significance was determined by the Student's t-test (twotailed) of means.

\section{Results}

\section{Physiologic parameters in control and streptozotocin-treated rats}

Serum glucose levels were determined at 6 weeks. In most groups of streptozotocin-treated animals, 65-80\% of the animals exhibited serum glucose concentrations between $180-230 \mathrm{mg} / \mathrm{dl}$; these animals were chosen for subsequent studies. Corresponding fed glucose values for the control group were in the range of $120-150 \mathrm{mg} /$ dl. A summary of animal weight, serum glucose and insulin levels, and pancreatic insulin content for the initial group of animals is presented in Table 1.

\section{Glucose tolerance}

Streptozotocin-treated rats demonstrated glucose intolerance similar to that observed in Type 2 diabetes. Serum was sampled at 15,45 and 90 min post-injection of glucose, and significant differences $(p<0.05)$ were evi-

Table 1. Physiologic characteristics of control and streptozotocintreated rats

\begin{tabular}{lllll}
\hline & $\begin{array}{l}\text { Weight } \\
(\mathrm{g})\end{array}$ & $\begin{array}{l}\text { Serum } \\
\text { glucose } \\
(\mathrm{mg} / \mathrm{dl})\end{array}$ & $\begin{array}{l}\text { Serum insulin Pancreatic } \\
(\mathrm{ng} / \mathrm{ml})\end{array}$ & $\begin{array}{l}\text { lnsulin } \\
(\mathrm{ng} / \mathrm{mg})^{\mathrm{b}}\end{array}$ \\
\hline $\begin{array}{l}\text { Control } \\
\text { Strepto- }\end{array}$ & $218 \pm 20(28)$ & $140 \pm 13(22)$ & $4.6 \pm 0.9(22)$ & $103.1 \pm 7.6(8)$ \\
$\begin{array}{l}\text { zotocin- } \\
\text { treated }\end{array}$ & & & & \\
\hline
\end{tabular}

Results expressed as mean \pm SEM. Number of animals or samples are given in parentheses a Statistically significant at $p<0.05 ;{ }^{b}$ ng insulin per mg pancreas (wet weight) 

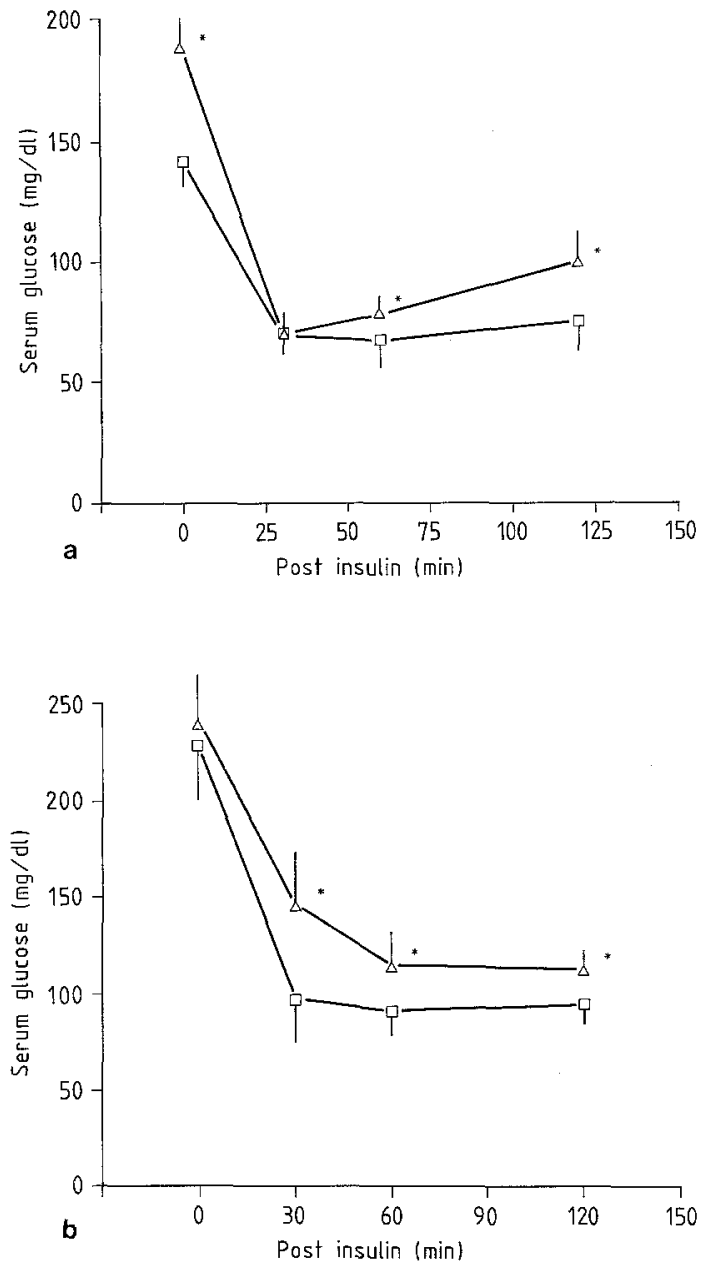

Fig. 1. a Serum glucose concentrations after intraperitoneal administration of $1.5 \mathrm{~g} / \mathrm{kg}$ glucose in a glucose tolerance test in 6-week-old control $(O-.-O)$ and streptozotocin-treated rats $(\Delta-\cdots \Delta)$. Serum samples were collected just prior to injection $(0)$ and at 15,45 , and $90 \mathrm{~min}$ post-dose $\left({ }^{*} p<0.05\right.$ compared to control). b Serum insulin levels for the control (O----O) and streptozotocin-treated animals $(\Delta---\Delta)$ during a representative glucose tolerance test

dent between control and streptozotocin-treated animals at each time point (Fig. 1 a). In addition, the increment from baseline was statistically different at each point; for example, at $45 \mathrm{~min}$ the difference from baseline in the streptozotocin-treated animals was 20 times the corresponding value for the control group $(p<$ 0.05 ). Serum insulin levels were also measured in the animals in several experiments, and the data indicate that the differences in serum glucose may be attributable to a blunted insulin secretory response (Fig. $1 \mathrm{~b}$ ).

\section{Insulin tolerance}

Serum samples were taken at 30,60 and 120 min postinjection of insulin (Fig. $2 \mathrm{a}$ ). At $30 \mathrm{~min}$ after insulin administration, glucose values were decreased to about
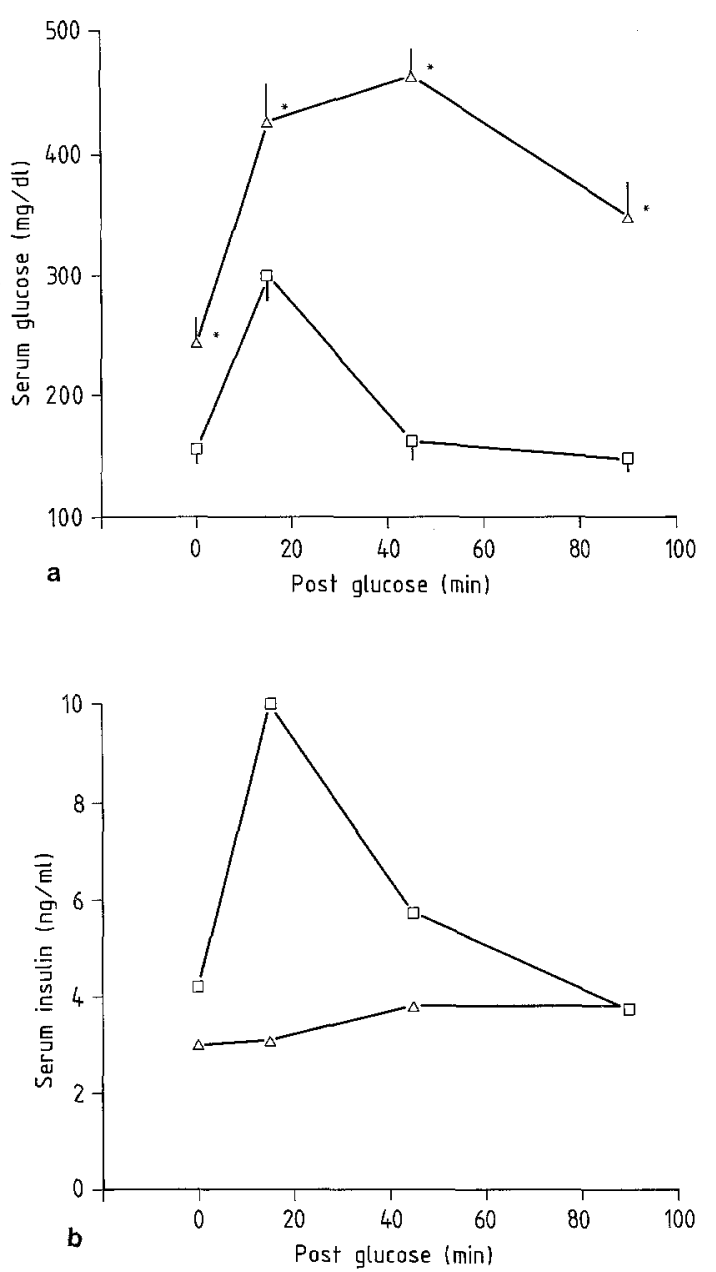

Fig. 2. a Serum glucose concentration following intraperitoneal administration of insulin $(1.0 \mathrm{U} / \mathrm{kg})$ in an insulin tolerance test in 6 week old control $(O---O$ and streptozotocin-treated rats $(\Delta---\Delta)$. Serum samples were collected just prior to injection $(0)$ and at 30,60 , and 120 min post-dose. Values represent the mean \pm SEM of 3 experiments, $n \geqslant 5$ animals/assay ( ${ }^{*} \mathrm{p}<0.05$ compared to control). b Serum glucose concentrations following intraperitoneal administration of $0.5 \mathrm{U} / \mathrm{kg}$ insulin $\left(\triangle \cdots-{ }^{---}\right)$or $1.0 \mathrm{U} / \mathrm{kg}$ insulin $\left(O_{---} O\right)$ in an insulin tolerance test in 6-week-old streptozotocin-treated rats. Values represent the mean \pm SEM of 4 experiments, $n \geqslant 4$ animals/assay $\left({ }^{*} p<\right.$ 0.05 compared to $1.0 \mathrm{U} / \mathrm{kg}$ )

$70 \mathrm{mg} / \mathrm{dl}$ in both the control group and streptozotocintreated animals. The net reduction in serum glucose was significantly greater for the streptozotocin-treated rats at both the 30 and $60 \mathrm{~min}$ points, suggesting an equivalent or possibly increased responsiveness to insulin. This response is insulin dose-dependent (Fig. 2b) and the slopes of the curves generated after injection of $0.5 \mathrm{U}$ or $1.0 \mathrm{U} / \mathrm{kg}$ insulin are similar. This implies that physiologic sensitivity to insulin (as well as maximal responsiveness) is maintained following streptozotocin treatment.

\section{Effect of sulfonylureas}

The response of streptozotocin-treated animals to an oral hypoglycaemic agent, tolazamide $(25 \mathrm{mg} / \mathrm{kg})$ ad- 


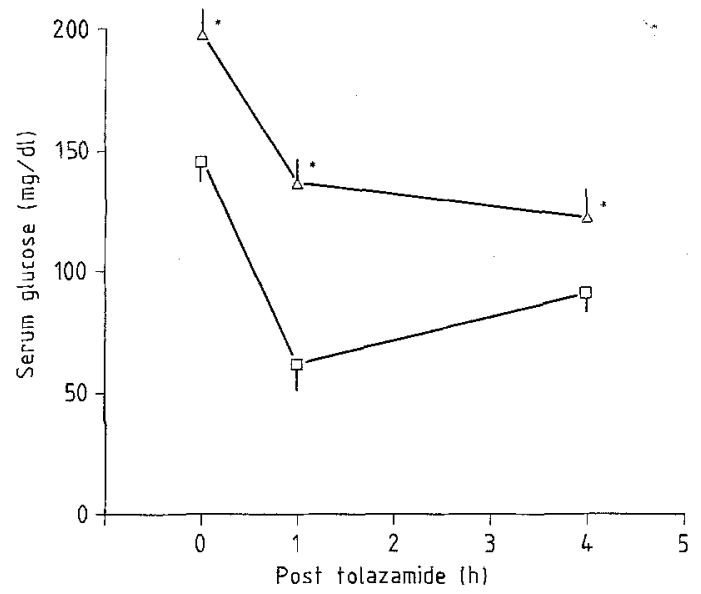

Fig. 3. Effect of tolazamide $(25 \mathrm{mg} / \mathrm{kg})$ on serum glucose concentrations in control $(O----O)$ and streptozotocin-treated rats $(\Delta----\Delta)$. Serum samples were collected just prior to sulfonylurea administration ( 0$)$ and at 1 and $4 \mathrm{~h}$ post-dose. Values represent the mean $\pm S E M$ of 3 experiments, $\mathrm{n} \geqslant 5$ animals/assay $\left({ }^{*} p<0.5\right.$ compared to control)

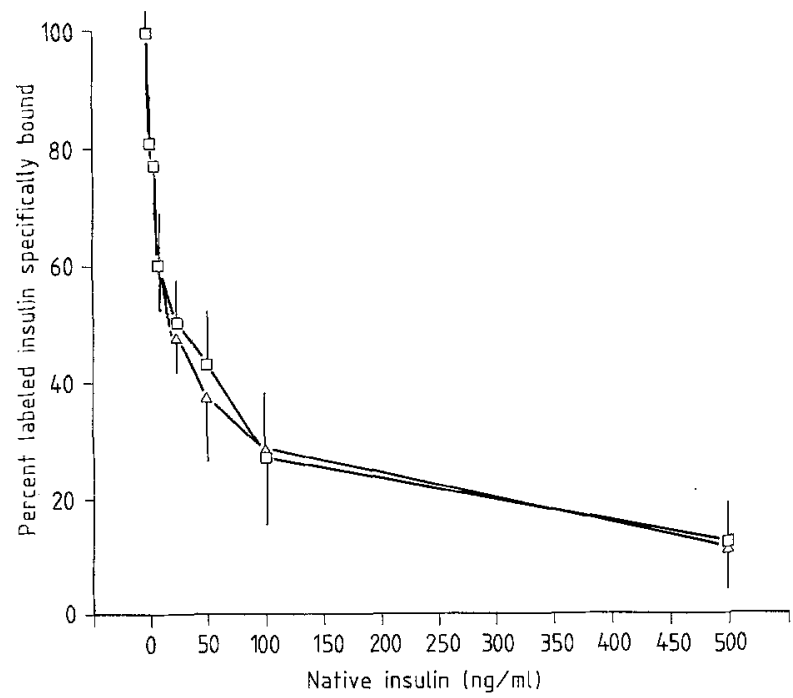

Fig.4. Specific binding of ${ }^{125} \mathrm{I}$-insulin $(0.6 \mathrm{ng} / \mathrm{ml})$ to adipocytes from control $\left(O \ldots-O_{0}\right)$ and streptozotocin-treated rats $(\Delta \cdots-\cdots)$. Radioligand was incubated with the cells for $60 \mathrm{~min}$ at $22^{\circ} \mathrm{C}$. Total, specific and non-specific binding, and insulin concentration required for $50 \%$ displacement were the same in both groups of cells. Values represent mean $\pm S E M$ of 4 experiments

ministered per os with $1 \%$ tween as a vehicle was examined (Fig. 3). The maximum net decrease in serum glucose due to tolazamide $(\sim 75 \mathrm{mg} / \mathrm{dl})$ was not different in the control group and streptozotocin-treated animals. However, this effect was achieved in $1 \mathrm{~h}$ in the control group, whereas $4 \mathrm{~h}$ were required to produce a comparable response in the streptozotocin-treated group.

\section{Cellular effects - insulin binding}

Insulin binding by adipocytes isolated from epididymal fat pads of the streptozotocin-treated and control rats was equivalent. Neither the specific binding of iodinated hormone nor the ability of unlabeled insulin to com-

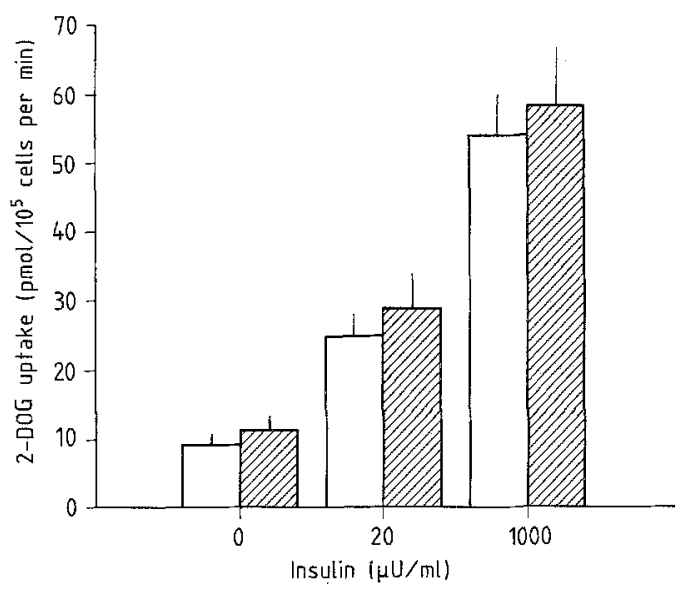

Fig. 5. Insulin enhancement of hexose uptake by adipocytes from control ( $\square$ ) and streptozotocin-treated rats (造). The rate of 2-deoxyD- $\left[1-{ }^{3} \mathrm{H}\right]$ glucose uptake $(0.1 \mathrm{mmol} / 1)$ was measured for $60 \mathrm{sec}$ at $37^{\circ}$. Neither the basal values nor the insulin-stimulated values were significantly different for the two conditions. Each bar represents the mean \pm SEM of 8 experiments

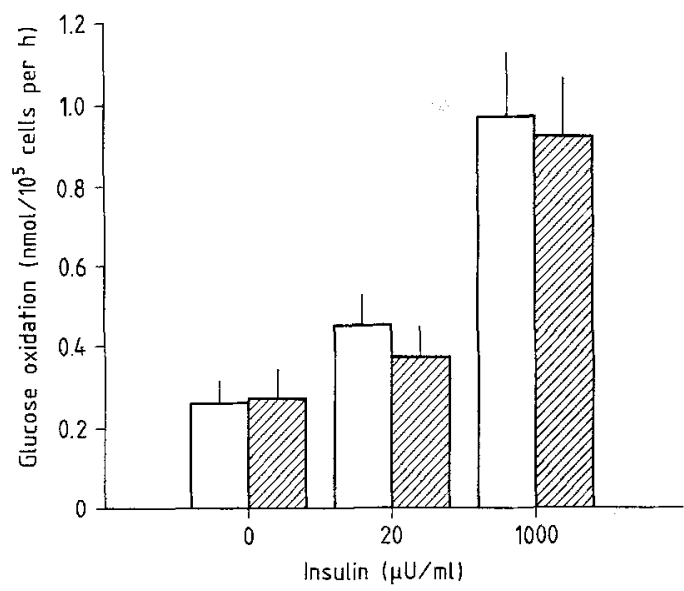

Fig. 6. Glucose oxidation by adipocytes from control ( $\square$ ) and streptozotocin-treated rats (图). Cells were incubated in the absence or presence of insulin with $0.1 \mathrm{mmol} /{ }^{14} \mathrm{C}$-D-glucose for $1 \mathrm{~h}$ at $37^{\circ}$. There were no significant differences in adipocyte responses between the control and streptozotocin-treated groups. Each bar represents the mean $\pm S E M$ of 8 experiments

pete for binding were influenced by the presence of physiologic glucose intolerance (Fig. 4). Scatchard analysis of the binding data indicated no significant differences in insulin receptor number or affinity. Insulin degradation over the course of the assay $(2-10 \%)$ was the same in cells from the two groups.

\section{Hexose uptake}

Glucose transport activity in adipocytes, monitored by the uptake of 2-deoxyglucose, was not altered in cells from the hyperglycaemic animals. As shown in Figure 5, neither basal glucose uptake nor insulin-stimulated glucose uptake in the presence of physiologic and pharmacologic levels of hormone were significantly dif- 
ferent for the two conditions. Uptake of 3-O-methylglucose at equilibrium was used to estimate cytosolic space (data not shown). Adipocytes from the streptozotocintreated group were slightly, but not significantly, smaller than those from the control group.

\section{Glucose oxidation}

In order to give a more complete assessment of the possible influence of chronic hyperglycaemia (6-week poststreptozotocin injection) on cellular biologic response, glucose oxidation was monitored in the absence or presence of sub-maximal and maximally effective insulin concentrations (Fig.6). Using a glucose concentration of $0.1 \mathrm{mmol} / 1$, at which transport is rate-limiting for metabolism [15], no significant differences in adipocyte metabolism were observed between cells from control and streptozotocin-treated animals.

\section{Discussion}

Several recent investigations, both in vivo and in vitro, have attempted to identify the basis for the abnormalities in glucose homeostasis following neonatal-streptozotocin treatment of Sprague-Dawley rats. It is clear from these studies that administration of this nitrosurea pancreatic B-cell-specific toxin [16] results in an incomplete destruction of insulin-producing cells in the neonates [17-19]. These B-cell-deficient animals are moderately hyperglycaemic ( $200 \mathrm{mg} \%$ serum glucose) when studied at 4-8 weeks post-treatment, and display a serum glucose response following glucose challenge similar to that observed in Type 2 diabetes. This glucose intolerance has been attributed to cellular and physiologic insulin resistance, which would provide another important similarity between the animal model and adult-onset diabetes. In contrast, however, our data suggest that insulin tolerance is not altered in the diabetic animals, and insulin resistance is not characteristic of isolated adipocytes.

In order to better define the pancreatic versus extrapancreatic locus of glucose intolerance, separate assays were run for responses to exogenous glucose (i. e. monitoring pancreatic activity) or insulin (i. e. monitoring peripheral activity). The response to exogenous insulin, in an insulin tolerance test, is not compromised by the hyperglycaemia and glucose intolerance characteristic of the streptozotocin-treated animals. These data are not consistent with the findings of Levy et al. [9], who reported that sub-maximal doses of insulin administered to streptozotocin-treated non-insulin-dependent rats resulted in decreased glucose disappearance rates compared to control animals. In that report it was suggested that streptozotocin treatment results in an acquired impairment in insulin action, most compatible with a deficit in cellular biologic response to insulin. These investigators employed concurrent administration of insulin and glucose to monitor glucose disposal. However, we have demonstrated that exogenous glucose alone will manifest significant differences in glucose disposal. This would tend to suggest that differences attributed to impaired insulin action in the presence of both exogenous glucose and insulin may reflect a predominant lesion at the level of glucose tolerance. Our data comparing insulin action in adipocytes isolated from control and streptozotocin-treated animals provides further support for this suggestion.

Adipocytes are well-established as a model target tissue in diabetes and obesity, and have been used in a number of other conditions associated with insulin resistance, such as uraemia [20] or acromegaly [21]. These cells do not play a major role in glucose homeostasis; however, they are well suited to study insulin action. These cells respond to physiologic levels of insulin in a reversible manner, and provide a homogeneous preparation in which insulin binding and biologic responses can be monitored. Analysis of the insulin binding data to adipocytes isolated from the control and streptozotocin-treated rats at 4-8 weeks of age demonstrate that neither insulin receptor number nor affinity was affected by glucose intolerance. This would suggest that the sensitivity of biological responses to insulin would also be maintained. Hexose transport and glucose oxidation were monitored in the presence of physiologic insulin concentration, and were equivalent for the control and streptozotocin-treated rat cells. However, impaired insulin action could be present concomitant with unaltered insulin sensitivity. Therefore, insulin action at maximally-effective levels of insulin or the insulin-mimickers vitamin $\mathrm{K}_{5}$ and hydrogen peroxide (data not shown) was investigated. The net maximal increase above basal activity was the same for cells from both groups, consistent with the absence of a post-receptor defect. The present findings are not in agreement with the study of Trent et al. [10], who examined insulin action in adipocytes isolated from rats 4-6 weeks post neonatal-streptozotocin treatment. They measured glucose metabolism in adipocytes from treated and control animals, and found significantly less substrate conversion in the cells from streptozotocin-treated rats. However, these results may reflect atypical cellular responsiveness in their assays. For example, half maximal and maximally effective insulin concentrations in their study were higher than established values [22-25], and there were differences between insulin concentrations required for half-maximal responses in glucose oxidation and lipid incorporation as well as in cells isolated from 4 week old versus 6 week old animals. These experimental parameters may account for discrepancies between their findings and this report. Our data is in accord with established parameters of insulin binding and kinetics of insulin bioresponse. The viability of our cell preparations was evidenced both by the acute experiments, and preservation of responsiveness following organ culture (data not shown) [26]. Again, no differences 
were observed resulting from streptozotocin treatment. These in vitro results are consistent with our in vivo observations of unimpaired insulin action in the hyperglycaemic animals.

Glucose intolerance resulting from reduced B-cell mass is clearly the predominant lesion in adult animals treated as neonates with streptozotocin. Other mechanisms including substrate recognition and the resultant secretory kinetics may also contribute to the abnormal glucose homeostasis. The time course and response to a non-glucose secretagogue, tolazamide, are indicative of reduced insulin and/or synthesis. The similarity between these findings and those using glucose as a secretagogue suggests that the primary lesion may be confined to reduced B-cell number.

The similarity between glucose intolerance in this model and adult-onset diabetes provides an experimental tool which can be used in more specific targeting of anti-diabetic agents. Since the streptozotocin treatment itself does not affect cellular response to insulin, direct changes can be observed in response to subsequent treatment with potential therapeutic agents. In addition, the differences between this model and Type 2 diabetes may provide important insights in understanding the pathogenesis of insulin restistance. The neonatal streptozotocin treatment represents a condition of glucose intolerance concurrent with intact insulin sensitivity and responsiveness. This suggests that hyperglycaemia and glucose intolerance may not be associated with the development of insulin resistance and altered response in insulin target tissues.

Acknowledgements. The authors wish to thank D. Fefer, T.M. Weckerly, and G.M.Cooke for their expert technical assistance. We also thank Dr. G. Weir for helpful suggestions regarding preparation of our experimental animals.

\section{References}

1. Ginsberg H, Rayfield EJ (1981) Effect of insulin therapy on insulin resistance in type II diabetic subjects - evidence for heterogeneity, Diabetes 30:739-745

2. Bergman RN, Phillips LS, Cobelli C (1981) Physiologic evaluation of factors controlling glucose tolerance in man - measurement of insulin sensitivity and B-cell glucose sensitivity from the response to intravenous glucose. J Clin Invet 68: 1456-1467

3. Reaven G, Silvers A, Farquhar J (1970) Study of the relationship between plasma insulin concentration and efficiency of glucose uptake in normal and mildly diabetic subjects. Diabetes 19: 571-578

4. Olefsky JM, Kolterman OG, Scarlett JA (1982) Insulin action and resistance in obesity and non-insulin-dependent type II diabetes mellitus. Am J Physiol 243/ E15-E30

5. Turner RC, Holman RR, Matthews D, Hockaday TDR, Peto J (1979) Insulin deficiency and insulin resistance interaction in diabetes: estimation of their relative contribution by feedback analysis from basal plasma insulin and glucose concentrations. Metabolism 28: 1086-1096

6. Nankervis A, Proietto J, Aitken P, Harewood M, Alford F (1982) Differential effects of insulin therapy on hepatic and peripheral insulin sensitivity in type 2 (non-insulin-dependent) diabetes. Diabetologia 23: 320-325

7. Wajngot A, Roovete A, Vranic M, Luft R, Efendic S (1982) Insulin resistance and decreased insulin response to glucose in lean type 2 diabetics. PNAS 79: 4432-4436

8. Weir GC, Clare ET, Zmachinski CJ, Bonner-Weir S (1981) Islet secretion in a new experimental model for non-insulin dependent diabetes. Diabetes 30:590-595

9. Levy J, Gavin JR III, Fausto A, Gingerich RL, Avioli LV (1984) Impaired insulin action in rats with non-insulin-dependent diabetes. Diabetes 33: 901-906

10. Trent DF, Fletcher DJ, May JM, Bonner-Weir S, Weir GC (1984) Abnormal islet and adipocyte function in young B-cell-deficient rats with near-normoglycaemia. Diabetes 33: 170-175

11. Rodbell MJ (1964) Metabolism of isolated fat cells. I. Effects of hormones on glucose metabolism and lipolysis. J Biol Chem 239 : $375-380$

12. Gliemann IK, Osterlind K, Vinten J, Gammeltoft S (1972) A procedure for measurement of distribution spaces in isolated cells. Biochim Biophys Acta 286: 1-9

13. Livingston JN, Lackwood DH (1974) Direct measurement of sugar uptake in small and large adipocytes from young and adult rats. Biochem Biophys Res Commun 61: 989-996

14. Czech MP (1976) Regulation of the D-glucose transport system in isolated fat cells. Mol Cell Biochem 11:51-63

15. Crofford OB (1968) The uptake and inactivation of native insulin by isolated fat cells. $J$ Biol Chem 243: 363-369

16. Srivastava LM, Bora PS, Bhatt SD (1982) Diabetogenic action of streptozotocin. Trends Pharmacol Sci 3: 376-378

17. Portha B, Picon L, Rasselin G (1979) Chemical diabetes in the adult rat as the spontaneous evolution of neonatal diabetes. Diabetologia 17: 371-377

18. Bonner-Weir S, Trent DF, Honey RN, Weir GC (1981) Responses of neonatal rat islets to streptozotocin- limited B-cell regeneration and hyperglycemia. Diabetes 30:64-69

19. Leahy JL, Bonner-Weir S, Weir GC (1984) Abnormal glucose regulation of insulin secretion in models of reduced B-cell mass. Diabetes $33: 667-673$

20. Maloff BL, McCaleb ML, Lockwood DH (1983) Cellular basis of insulin resistance in uremia. Am J Physiol 245: E178-E 184

21. Maloff BL, Levine JH, Lockwood DH (1980) Direct effects of growth hormone on insulin action in rat adipose tissue maintained in vitro. Endocrinology 107: 538-544

22. Maloff BL, Lockwood DH (1981) In vitro effects of a sulfonylurea on insulin action in adipocytes - potentiation of insulin-stimulated hexose transport. J Clin Invest 68: 85-90

23. Hissin PJ, Foley JE, Wardzala LJ, Karnieli E, Simpson IA, Salans LB, Cushman SW (1982) Mechanism of insulin-resistant glucose transport activity in the enlarged adipose cell of the aged, obese rat. J Clin Invest 70: 780-790

24. Lavau M, Fried SK, Susini C, Freychet $P$ (1979) Mechanism of insulin resistance in adipocytes of rats fed a high-fat diet. $\mathrm{J}$ Lipid Res 20: 8-16

25. Kobayashi M, Olefsky JM (1979) Effect of experimental hyperinsulinemia on intracellular glucose metabolism of isolated adipocytes. Diabetologia 17:111-116

26. Malchoff DM, Maloff BL, Livingston JN, Lockwood DH (1982) Influence of dexamethasone on insulin action: inhibition of basal and insulin-stimulated hexose transport is dependent on length of exposure in vitro. Endocrinology 110: 2081-2087

Received: 7 October 1985

and in revised form: 21 February 1986

Dr. Bruce L. Maloff

DuPont Company, E 400/4223

Wilmington, DE 19898

USA 